\title{
Evaluating University Students' Inference Making Ability: A Study at Bachelor Level in Pakistan
}

\author{
Muhammad $\operatorname{Din}^{1} \&$ Mamuna Ghani ${ }^{2}$ \\ ${ }^{1}$ Dept. of English, The Islamia University of Bahawalpur, Pakistan \\ ${ }^{2}$ Chairperson Dept. of English, Dean Faculty of Arts \& Islamic Learning, The Islamia University of Bahawalpur, \\ Bahawalpur, Pakistan \\ Correspondence: Muhammad Din, PhD Scholar, Dept. of English, The Islamia University of Bahawalpur, \\ Pakistan. E-mail: mduaau@gmail.com
}

Received: June 30, 2019 Accepted: July 23, 2019 Online Published: September 6, 2019

doi:10.5539/ijel.v9n5p351 URL: https://doi.org/10.5539/ijel.v9n5p351

\begin{abstract}
Inference means the process of deriving a conclusion from a set of premises, including a conclusion that is probably in relation to the premises. This study has aimed to evaluate university students' inference making ability. To explore this aim, the present study has set five research objectives which include to understand university students' attitude towards critical thinking subset of making inferences, find out the relationship between university students' attitude towards making inferences and their ability in making inferences, know whether critical thinking is a positive predictor for the overall score of critical thinking test (CTT), evaluate university students' performance in exhibiting their attitude towards critical thinking and in critical thinking test (CTT) taken by them and understand the variance based on university students' gender, location and medium of instruction in their attitude towards critical thinking inference and their ability of making inferences. To achieve these objectives, the researcher has used quantitative research methodology. The participants of this study consist of 550 male and female university students of different state-run colleges of Punjab (Pakistan). Critical thinking inventory (CTI) and Watson-Glaser's Critical Thinking Appraisal (WGCTA) (2002) have been used to collect data from the subjects of the study. The researcher used SPSS (XX) to analyze the collected data. The findings of this study reveal that the university EFL leaners have highly positive attitude towards making inferences but their inference making ability does not correspond with their attitude toward inference making skill.
\end{abstract}

Keywords: inference making, critical thinking, set of premises, university students

\section{Introduction}

Inference means the process of deriving a conclusion from a set of premises, including a conclusion that is probably in relation to the premises (McArthur, 1992, p. 515). Oakhill et al. (1999) style inference to establish link between ideas and fill in the detail that has not been explicitly mentioned. Inference plays an important role in the process of constructing text representations that are coherent and integrated. Paul and Elder (2011) define inference that "an inference is a step of the mind, an intellectual act by which one concludes that something is true in the light of something else's being true or seeming to be true". Inference means a network that connects individual events and facts into meaningful relations. Thus, reader resorts to text-connecting inferences and knowledge-based inferences in the process of reading comprehension (Hall \& Barnes, 2016). Kispal (2008) has defined inference as "the ability to use two or more pieces of information from a text in order to arrive at a third piece of information that is implicit".

\subsection{Critical Thinking and Inference Making}

Critical thinking has gained paramount importance in foreign language teaching. So, the enhancing and honing the foreign language learners' critical thinking is considered one of the most important requisites in the teaching and learning of a foreign language. Halpern (2003) styles critical thinking a "vital necessity" of the 21 st century particularly in the wake of information explosion. It is a prime requisite that the citizens of this century must equip themselves with the ability of "knowing how to learn" and "knowing how to think clearly" about the fast-increasing information. Critical thinking means the ability of collecting, evaluating and using information 
effectively and appropriately.

In critical thinking, formulating inferences is one of the most important components. The literature related to critical thinking particularly the definitions presented by the experts of this domain highlight the importance of inference in critical thinking. For instance, Halpern (2003) defines critical thinking as thinking that involves "solving problems, formulating inference, calculating likelihood, and making decisions". The definition of critical thinking given by the American Philosophical Association Project (APAP) styles inference, evaluation, analysis and interpretation of the results of purposeful and self-regulatory judgement (Facione \& Facione, 1996). Watson and Glaser (2002) have also associated critical thinking with the abilities of inferences, recognition of assumption, interpretation of information and evaluation of arguments.

\subsection{Inference Making and Reading Comprehension}

Inference making ability helps readers to infer implied meanings, resolve ambiguities and vagueness and fill gaps in spatial, temporal and causal descriptions by supplementing their situation model representation which is one of the three levels of text representation. These researchers also claim that readers are required to construct coherent situation model from text by connecting the core ideas they read to the previous information they have (Bos et al., 2016). Inference making is such a skill as is very essential in reading comprehension because inference skills and background knowledge of readers establish situation model which helps reading comprehension. Therefore, inferencing constitutes a solid foundation for text base and situation model which are of crucial significance in reading comprehension (Savic, 2018). Currie and Cain (2015) also highlight the importance of inferencing in reading because inferencing skills help readers integrate information within text by unearthing implicit information. Different studies (Currie \& Cain, 2015; Cain \& Oakhill, 1999; Broek et al., 2015; Graesser, Singer, \& Trabasso, 1994) have explained the role of different inference skills-coherence inference, elaborative inference, global inference, off-line inference and on-line inference-in comprehensive reading comprehension.

\subsection{Objectives of the Study}

The objectives of this study have been given as follows;

- To understand university students' attitude towards critical thinking subset of making inferences.

- To find out the relationship between university students' attitude towards making inferences and their ability in making inferences.

- To understand whether critical thinking is a positive predictor for the overall score of critical thinking test (CTT).

- To evaluate university students' performance in exhibiting their attitude towards critical thinking and in critical thinking test (CTT) taken by them.

- To understand the variance based on university students' gender, location and medium of instruction in their attitude towards critical thinking inference and their ability of making inferences.

\subsection{Research Questions of the Study}

The present study strives to find answer to some research questions which have been given below;

- What is university students' attitude towards critical thinking subset of making inferences?

- What is the relationship between university students' attitude towards making inference and their ability in making inferences?

- To what level does critical thinking predict the overall score of critical thinking test (CTT)?

- What is the university students' performance in demonstrating their attitude towards critical thinking and in critical thinking test (CTT) taken by them?

- What is the variance based on university students' gender, location and medium of instruction in their attitude towards critical thinking inference and their ability of making inferences?

\section{Literature Review}

Marzano (2010) believes that inference is one of those cognitive processes which are fundamental to higher-order thinking. It can be of paramount importance if students are made to realize the fact that they are always making inferences. To Marzano, inference means just filling in the information that has not been directly presented. He claims that there are two types of which can be made by students and they are default inference and reasoned inference. Default inference is an automatic assumption whereas reasoned inference is a conclusion 
that is based on available information. Marzano (2010) also maintains that examining the validity of thinking and the truth of the premises is very useful as they lead to inference. To this end, he recommends Four-Question Strategy which the researcher's brand "elaborative interrogation" and it has been derived from Ozgunger and Guthrie (2004). This "elaborative interrogation" includes the questions like 'what my inference is', "what information I used to make inference', 'how good my thinking was', and 'if I need to change my thinking'. Posing these questions paves the way for stepping into higher-order thinking. According to Schoot et al. (2010), inference making training renders very important payoffs as it helps students develop deep level of text comprehension and successful transfer of learning. Training in reference making also ensures students' increased reading motivation and their "good performance on the probe verification task".

Fahimeh and Afsaneh (2016) have carried out a study to find relationship between EFL university students' inference making, deduction and self-monitoring and language achievement particularly reading and writing achievement. The subjects of this study consisted of 120 male and female EFL university students. These researchers have used Watson-Glaser's Critical Thinking Appraisal (WGCTA) and Self-Regulation Trait (SRT) Questionnaire. According to the researchers, there is a significant correlation between inference making and language achievement $(\mathrm{r}=0.310, \mathrm{p}<0.05)$, inference making and writing achievement $(\mathrm{r}=0.440, \mathrm{p}<0.05)$ and inference making and reading achievement $(\mathrm{r}=0.410, \mathrm{p}<0.05)$. This study also claims that there is significant correlation between self-monitoring and language achievement and deduction and language achievement. The researchers also maintain that inference making, deduction and self-monitoring are very significant and positive predictors for language achievement. They round off their discussion by claiming that these three subcomponents of critical thinking make EFL university learners develop language competence and improve their language achievement.

Ahour and Ranjbar (2016) have conducted an experimental study to determine which lexical inferencing strategies Iranian EFL learners use at text and sentence levels and of text and sentence which level is more effective for lexical inferencing. The subjects $(\mathrm{n}=55)$ of this study are the male and female students of lower intermediate class. The researchers have used 2000 vocabulary level test and questionnaire to materialize the objectives of their study. This study has found that the Iranian EFL learners mostly resort to local context and guess. Apart from these strategies, these EFL learners use discourse context, background knowledge and syntactic knowledge for lexical inferencing. Bos et al. (2016) have conducted an experimental study to improve reading comprehension skill through a situation model approach by training inference making skills. The participants $(\mathrm{n}=143)$ of this study were the third and fourth grade students. The researchers have conducted inference making training program consisting of eight 30-minute instructional lessons. This program also included computer-based lessons. An approach of individual practice, modelling, guided practice and direct instruction was resorted to in instructional lessons. This study reports that the post-test performance of the experimental and control group was quite different. The results of this experimental study reveal that the experimental group has higher reading comprehension, better inferencing making skills and higher reading motivation. Broek et al. (2015) also claim that the role of inference skills in creating coherence by connecting parts of a text has been recognized by cognitive models of reading and comprehension. Savic (2018) has conducted a study to identify EFL young learners' inference skills. This study has used mixed-method approach to collect quantitative and qualitative data. The participants of this study are 90 fifth-grade students. The researcher has used reading tasks to collect data from the participants of this study. This study has found that young EFL learners need to resort to global and local inference skills for comprehensive understanding of a text. This study also reports that successful comprehenders use and combine a variety of inferences, use their life experiences and world knowledge. On the other hand, less successful comprehenders mostly focus on word meanings instead of monitoring their reading. Hassanzadeh et al. (2019) have carried out an experimental study to explore the effect of the instruction of lexical inferencing on EFL learners' vocabulary depth and breadth. The participants of this study are 45 Iranian students of EFL course. The researchers have used Preliminary English Test (PET), Schmitt et al.'s test of vocabulary breadth and Read's Word Associate Test as research instruments of this study. This study has used Nassaji's (2006) model for teaching lexical inference and this model consists of three stages i.e., identifying, evaluation and monitoring. This study reports that the students of the experimental group who had lessons on inferencing strategies have got higher vocabulary breadth and depth (M $=24.87)$ than the students of control group $(\mathrm{M}=21.23)$.

The review of the literature reveals the paucity of such empirical studies as have investigated and evaluated EFL learners' attitude towards inference making and their ability of drawing inference. As far as the researcher knows, no study has been carried out in the Pakistani context in this regard. Keeping in view this gap, the researcher has strived, in the present study, to evaluate the Pakistani university EFL learners' attitude towards critical thinking 
particularly inference making skill and evaluate whether these EFL learners are able to reflect their ability of drawing inference in a critical thinking test (CTT).

\section{Research Methodology}

This study is primarily quantitative in nature. So, the researcher has used the quantitative research methodology.

\subsection{Population of the Study}

All the male and female students of bachelor level (University Students) of Punjab (Pakistan) are the target population of this study.

\subsection{Sample of the Study}

The sample of the present study is 550 male and female university students of B.Sc. (4th Year) Class (Bachelor Level) from different state-run colleges of Punjab (Pakistan). For the administration of the questionnaire, such participants were selected as could prove the representative of the population of the study.

\subsection{Research Instruments}

The researcher has used two research tools i.e. critical thinking inventory (CTI) and Watson-Glaser's Critical Thinking Appraisal (WGCTA) (2002) as critical thinking test (CTT). The detail of these two research tools has been given as follows;

\subsubsection{Critical Thinking Inventory (CTI)}

The researcher has designed critical thinking inventory (CTI) to know the university students' attitude towards making inference which is a subset of critical thinking ability. It consists of twelve questionnaire items. All the questionnaire items of this research instrument are close ended on Likert scale from "strongly agree" to "strongly disagree". Prior to its use for the main study, the researcher got feedback from his supervisor and two experts to ensure the validity of this research tool. The critical thinking inventory (CTI) was also piloted to check its reliability. The sample of this piloting phase comprises of 50 university students of B.Sc. (4th Year) class. First, the researcher briefed the participants regarding the nature and the objectives of the study. The participants were assured that the data collected from them would be kept in absolute confidentiality and anonymity. They were also told that they had the right to withdraw from this study at any time they liked. The reliability analysis for CTI Inference has been given as follows;

Table 1. Reliability analysis for CTI inference

\begin{tabular}{lll}
\hline No. of Items & Models Applied & Reliability Scale \\
\hline 12 & Conbach's Alpha & .813 \\
& Guttman Split-Half Coefficient & .721 \\
& Parallel Reliability of Scale (Unbiased) & .852 \\
& Split-half Reliability Correlation between Forms & .820 \\
\hline
\end{tabular}

\subsubsection{Watson-Glaser's Critical Thinking Appraisal (WGCTA)}

To appraise the participants' critical thinking ability and logical reasoning, the researcher has adopted an abridged version of Watson-Glaser's Critical Thinking Appraisal (WGCTA) (2002) as critical thinking test (CTT) with some modification. Basically, CTA comprises five subsets critical thinking which consist of 82 points but the researcher has used one subset of Inference in this study.

\subsection{Scale for Measuring University Students' Performance}

The researcher has set a scale to measure the performance of the participants' performance in CTI and CTT. To this end, this study has categorized the students' performance into four categories i.e., excellent, very good, average and poor based on the percentage of the score obtained by them. The details of this scale have been presented in a table given as follows;

Table 2. Performance categories

\begin{tabular}{lll}
\hline S. No. & Percentage of Score & Category \\
\hline 1 & $81-100$ & Excellent \\
2 & $61-80$ & Very Good \\
3 & $31-60$ & Average \\
4 & $00-30$ & Poor \\
\hline
\end{tabular}




\section{Results and Discussion}

The data collected with the help of critical thinking inventory (CTI) and critical thinking test (CTT) were fed into SPSS (XX) for statistical analysis.

\subsection{University Students' Attitude Towards Critical Thinking}

The first research question of the present study is to know what university students' attitude is towards critical thinking subset of "making inferences". The researcher has used a critical thinking inventory (CTI) to find the answer to this research question. The response of the participants of this study to CTI has been presented in the table given as follows;

Table 3. Participants' response to CTI with mean and standard deviation

\begin{tabular}{|c|c|c|c|c|c|c|c|c|}
\hline S. No. & Questionnaire Item & SA & $\mathbf{A}$ & NO & DA & SDA & $\mathbf{M}$ & SD \\
\hline 1 & I routinely reflect as I read. & 201 & 329 & 7 & 7 & 6 & 4.29 & .664 \\
\hline 2 & As I read a text, I also monitor how I am reading. & 179 & 334 & 6 & 28 & 3 & 4.20 & .743 \\
\hline 3 & $\begin{array}{l}\text { I connect the core ideas in a text to other core ideas I } \\
\text { understand. }\end{array}$ & 181 & 316 & 9 & 42 & 2 & 4.15 & .814 \\
\hline 4 & $\begin{array}{l}\text { I often pause to think about the meaning of a passage } \\
\text { that I don't immediately understand. }\end{array}$ & 265 & 259 & 5 & 15 & 6 & 4.39 & .742 \\
\hline 5 & $\begin{array}{l}\text { I try my best to comprehend the clarity and precision of } \\
\text { a given passage. }\end{array}$ & 183 & 329 & 5 & 32 & 1 & 4.20 & .742 \\
\hline 6 & I can identify the literal meaning of a given passage. & 139 & 338 & 7 & 64 & 2 & 4.00 & .875 \\
\hline 7 & $\begin{array}{l}\text { I pay attention to figures of speech to make reasonable } \\
\text { inferences. }\end{array}$ & 69 & 343 & 7 & 128 & 3 & 3.63 & .992 \\
\hline 8 & I can read between the lines. & 104 & 305 & 10 & 124 & 7 & 3.68 & 1.060 \\
\hline 9 & $\begin{array}{l}\text { I can use various clues to help me make a guess when I } \\
\text { can't understand the text. }\end{array}$ & 221 & 287 & 3 & 35 & 4 & 4.25 & .817 \\
\hline 10 & I can easily draw a valid inference from a text. & 108 & 343 & 13 & 84 & 2 & 3.86 & .919 \\
\hline 11 & $\begin{array}{l}\text { I can fill in information that is not directly presented in a } \\
\text { text. }\end{array}$ & 67 & 289 & 18 & 164 & 12 & 3.43 & 1.104 \\
\hline 12 & I hunt for clues to make inference while reading a text. & 150 & 323 & 5 & 67 & 5 & 3.99 & .923 \\
\hline
\end{tabular}

Table 2 shows university students' response to CTI and their attitude towards critical thinking. According to this table, the majority of the participants have strongly agreed and agreed to the questionnaire statements which were put to them to seek their opinion. For instance, $36.5 \%$ of the participants have strongly agreed and $59.8 \%$ agreed that they reflect when they read and $32.5 \%$ have strongly agreed and $60.7 \%$ have agreed that they monitor when they read some text. Of the participants of this study, $90.4 \%$ maintain that they connect the core ideas in text to other core ideas they understand, $95.3 \%$ students claim that they pause to think the meaning of a text when they do not immediately understand and $93.1 \%$ try their best to comprehend the clarity and precision of a given passage. Moreover, $25.3 \%$ students have strongly agreed and $61.5 \%$ have agreed that they can identify the literal meaning of a given passage, $12.5 \%$ have strongly agreed and $62.4 \%$ have agreed that they pay attention to figures of speech while doing reading and $74.4 \%$ participants have claimed that they can read between the lines. According to the response rendered by the participants of the study, $92.4 \%$ students can use various clues to make a guess to reach the meaning of a text. Regarding the drawing of a valid inference from a given text, $19.6 \%$ students have strongly agreed and $62.4 \%$ agreed that they can do this whereas $64.7 \%$ participants claim that they can fill in the information that is not directly presented in a text. On the other hand, $86 \%$ students have maintained that they hunt for clues to make inference while reading text. These findings reveal that university students have highly positive attitude towards making inference and they resort to every strategy to make inference while reading a text.

\subsection{Correlation Between CTI \& CTT Inference}

The present study has aimed to find correlation between university students' attitude toward critical thinking and their performance in critical thinking test (CTT) taken by them. To this end, the researcher has computed Pearson product-moment correlation. The results of this correlation have been presented in a table given as follows; 
Table 4. Correlation between CTI and CTT inference

\begin{tabular}{lll}
\hline & CTI Inference & CTT Inference \\
\hline Pearson Correlation & 1 & $.155^{* *}$ \\
Sig.(2-tailed) & & .000 \\
$\mathrm{~N}$ & & 550 \\
\hline
\end{tabular}

Note. ${ }^{* *}$. Correlation is significant at the 0.01 level (2-tailed).

Table 3 show that there is significant positive correlation between university students' attitude towards critical thinking (CTI) and their overall score in critical thinking test (CTT).

\subsection{CTI-A Predictor for Critical Thinking Ability}

The present study has also aimed to explore how much university students' attitude towards critical thinking predicts their critical thinking ability. To this end, the researcher has conducted a multiple regression analysis.

Table 5. R square table for CTI inference

\begin{tabular}{lllll}
\hline Model & R & R Square & Adjusted R Square & Std. Error of the Estimate \\
\hline 1 & $.161(\mathrm{a})$ & .026 & .024 & 8.06249 \\
\hline a. Predictors: (Constant), CTI Inference & & \\
b. Dependent Variable: Score of Overall Critical Thinking Test (CTT) & \\
\hline
\end{tabular}

The correlation coefficient between CTI inference and overall critical thinking test (CTT) is 0.161 . The R Square value .026 and it shows that 2.6 percent of the variation in these university students' critical thinking ability can be explained by taking their overall critical thinking test (CTT) into account.

Table 6. ANOVA table of regression

\begin{tabular}{lllllll}
\hline Model & & Sum of Squares & df & Mean Square & F & Sig. \\
\hline 1 & Regression & 945.456 & 1 & 945.456 & 14.545 & $.000(\mathrm{a})$ \\
& Residual & 35622.079 & 548 & 65.004 & & \\
& Total & 36567.535 & 549 & & & \\
\hline
\end{tabular}

Note. a Predictors: (Constant), CTI Inference; b Dependent Variable: Score f Overall Critical Thinking Test (CTT).

The overall regression model is significant $(\mathrm{F}(1,548)=14.545, \mathrm{p}=.000(\mathrm{p}<.001))$. This indicates that there is significant regression relation between CTI inference and overall critical thinking test (CTT).

Table 7. Results of regression analysis

\begin{tabular}{lllllll}
\hline Model & \multicolumn{2}{l}{ Unstandardized Coefficients } & Standardized Coefficients & \multicolumn{1}{c}{ t } & \multirow{2}{*}{ Sig. } \\
\cline { 2 - 5 } & B & Std. Error & Beta & & \\
\hline 1 & (Constant) & 18.634 & 3.514 & & 5.303 & .000 \\
& CTI Inference & .278 & .073 & .161 & 3.814 & .000 \\
\hline
\end{tabular}

Note. a Dependent Variable: Score of Overall Critical Thinking Test (CTT) Inference.

The intercept is 18.634 and it indicates if we do not consider critical thinking then the average score obtained by a candidate is 18.634 which is significant i.e. it cannot be considered zero. The slope of overall CTI Inference is .278 which means if critical thinking is increased by one step i.e. from strongly disagree to disagree then the score increased is .278 . The P-Value is $0.000(\mathrm{p}<.001)$ which shows it is a significant change. These results reveal that critical thinking can predict 2.6 percent of university students' critical thinking ability.

\subsection{University Students' Performance in CTI and CTT}

This study aimed to find an answer to the research question what university students' performance is in demonstrating their attitude towards critical thinking and in critical thinking test (CTT) taken by them. The researcher has categorized these students' performance in four categories i.e., excellent, very good, average and poor. The performance of the subjects of this study in CTI and CTT has been presented in the table given as follows; 
Table 8. Performance of university students in CTI and CTT

\begin{tabular}{llllll}
\hline & Excellent & Very Good & Average & Poor & Total \\
\hline CTI Inference & 320 & 226 & 4 & - & 550 \\
CTT Inference & 193 & 179 & 111 & 67 & 550 \\
\hline
\end{tabular}

Table 7 demonstrates the performance of the university students in CTI and CTI in four different categories. According to this table, there are $58.18 \%$ (320) students who have got excellent score, $41.09 \%$ (226) students have achieved very good score and $0.73 \%$ (4) students have scored average score in critical thinking inventory (CTI). But there is not a single student whose score is zero in CTI. On the other hand, the results of this study show that there are $35.09 \%$ (193) who have got excellent score, $32.55 \%$ (179) have scored very good score, $20.18 \%$ (111) have got average score and $12.18 \%$ (67) students have achieved poor score in critical thinking test (CTT). These findings show that there is a decrease of $39.69 \%$ in CTT score of the students who had got excellent score in CTI, $20.8 \%$ decline in the category of "very good". But these findings also demonstrate that there is $96.40 \%$ increase in the category of "average" and there is $100 \%$ increase in the number of the students who have got poor score in CTT as there was no student who had got poor score in CTI. These findings also reveal that though these university students have highly positive attitude towards critical thinking but they remain unable to perform in critical thinking test (CTT) in line with their response to CTI. In other words, their performance does not speak of their attitude towards critical thinking. The findings of the study conducted by Cain et al. (2001) also report that poor memory, incorrect premise recall and integration failure are the reasons for students' inference failure. Warnidah et al. (2016) have also reached the findings that students face moderate difficulties in inferencing while reading but the percentage of difficulties is very high when they come to make inferences regarding the author's attitude.

\subsection{Variance}

The fifth research question of the present study was to find an answer to the question what variance based on university students' gender, location and medium of instruction is in their attitude towards critical thinking inference and their ability of making inferences. In other words, this study aimed to understand the difference of the participants' performance in CTI and CTT based on their gender, location and medium of instruction. To this end, the researcher computed Independent samples t-test. The results of this test have been given as follows;

Table 9. Gender based variance in CTI

\begin{tabular}{llllll}
\hline & Gender & N & Mean & Std. Deviation & Std. Error Mean \\
\hline CTI Inference & Male & 243 & 46.4650 & 4.64547 & .29801 \\
& Female & 307 & 49.3225 & 4.40850 & .25161 \\
\hline
\end{tabular}

Table 10. Results of independent samples T-Test

\begin{tabular}{|c|c|c|c|c|c|c|c|c|}
\hline & & \multicolumn{2}{|c|}{$\begin{array}{l}\text { Levene's Test for } \\
\text { Equality of Variances }\end{array}$} & \multicolumn{5}{|c|}{ t-test for Equality of Means } \\
\hline & & $\mathrm{F}$ & Sig. & $\mathrm{t}$ & df & $\begin{array}{l}\text { Sig. } \\
\text { (2-tailed) }\end{array}$ & $\begin{array}{l}\text { Mean } \\
\text { Difference }\end{array}$ & $\begin{array}{l}\text { Std. Error } \\
\text { Difference }\end{array}$ \\
\hline \multirow[t]{2}{*}{ CTI Inference } & Equal variances assumed & .264 & .607 & -7.371 & 548 & .000 & -2.85745 & .38765 \\
\hline & Equal variances not assumed & & & -7.326 & 506.458 & .000 & -2.85745 & .39002 \\
\hline
\end{tabular}

The findings of the present study reveal that there is a significant difference in CTI scores for male $(\mathrm{M}=46.4650$, $\mathrm{SD}=4.64547)$ and female students $(\mathrm{M}=49.3225, \mathrm{SD}=4.40850)$. These findings show that female students have performed better in CTI than male students. It means that female students have more positive attitude towards critical thinking than male students. The results of the independent samples t-test show that the difference in the performance of the participants in CTI based on their gender is significant $(\mathrm{p}=.000<0.01)$.

Table 11. Location based variance in CTI

\begin{tabular}{llllll}
\hline & Location & N & Mean & Std. Deviation & Std. Error Mean \\
\hline CTI Inference & Urban & 269 & 48.1264 & 4.68950 & .28592 \\
& Rural & 281 & 47.9964 & 4.77381 & .28478 \\
\hline
\end{tabular}


Table 12. Results of independent samples T-Test

\begin{tabular}{|c|c|c|c|c|c|c|c|c|}
\hline & & \multicolumn{2}{|c|}{$\begin{array}{l}\text { Levene's Test for } \\
\text { Equality of Variances }\end{array}$} & \multicolumn{3}{|c|}{ t-test for Equality of Means } & \multirow[b]{2}{*}{$\begin{array}{l}\text { Mean } \\
\text { Difference }\end{array}$} & \multirow[b]{2}{*}{$\begin{array}{l}\text { Std. Error } \\
\text { Difference }\end{array}$} \\
\hline & & $\mathrm{F}$ & Sig. & $\mathrm{t}$ & $\mathrm{df}$ & $\begin{array}{l}\text { Sig. } \\
(2 \text {-tailed })\end{array}$ & & \\
\hline CTI Inference & $\begin{array}{l}\text { Equal variances assumed } \\
\text { Equal variances not assumed }\end{array}$ & .004 & .950 & $\begin{array}{l}.322 \\
.322\end{array}$ & $\begin{array}{l}548 \\
547.632\end{array}$ & $\begin{array}{l}.748 \\
.748\end{array}$ & $\begin{array}{l}.12995 \\
.12995\end{array}$ & $\begin{array}{l}.40371 \\
.40355\end{array}$ \\
\hline
\end{tabular}

This study has found that there is difference in CTI scores of the urban students $(\mathrm{M}=48.1264, \mathrm{SD}=4.68950)$ and rural students $(\mathrm{M}=47.9964, \mathrm{SD}=4.77381)$. This difference demonstrates that urban students have shown slightly more positive attitude towards critical thinking than rural students. These results show that the difference in the performance of the participants in CTI based on their location is not significant as p-value is greater than 0.05. These results show that urban and rural background of the students does not have so much effect on their attitude towards critical thinking.

Table 13. Medium of instruction-based variance in CTI

\begin{tabular}{llllll}
\hline & Medium & $\mathrm{N}$ & Mean & Std. Deviation & Std. Error Mean \\
\hline CTI Inference & English & 445 & 48.2607 & 4.68411 & .22205 \\
& Urdu & 105 & 47.2095 & 4.84509 & .47283 \\
\hline
\end{tabular}

Table 14. Results of independent samples T-Test

\begin{tabular}{|c|c|c|c|c|c|c|c|c|}
\hline & & \multicolumn{2}{|c|}{$\begin{array}{l}\text { Levene's Test for } \\
\text { Equality of Variances }\end{array}$} & \multicolumn{3}{|c|}{ t-test for Equality of Means } & \multirow[b]{2}{*}{$\begin{array}{l}\text { Mean } \\
\text { Difference }\end{array}$} & \multirow[b]{2}{*}{$\begin{array}{l}\text { Std. Error } \\
\text { Difference }\end{array}$} \\
\hline & & $\mathrm{F}$ & Sig. & $\mathrm{t}$ & $\mathrm{df}$ & $\begin{array}{l}\text { Sig. } \\
\text { (2-tailed) }\end{array}$ & & \\
\hline \multirow[t]{2}{*}{ CTI Inference } & Equal variances assumed & .024 & .877 & 2.055 & 548 & .040 & 1.05115 & .51156 \\
\hline & Equal variances not assumed & & & 2.012 & 153.185 & .046 & 1.05115 & .52238 \\
\hline
\end{tabular}

So far as the variance based on the medium of instruction for CTI and CTT is concerned, the present study has found that there is a significant difference in the scores of CTI for English medium students $(\mathrm{M}=48.2607, \mathrm{SD}=$ 4.68411) and Urdu medium students $(\mathrm{M}=47.2095, \mathrm{SD}=4.84509)$. These results show that the difference in the performance of the participants in CTI based on their medium of instruction is significant $(p=.04<.05)$. This shows that English medium students have more positive attitude towards critical thinking than Urdu medium students.

Table 15. Gender based variance in CTT

\begin{tabular}{llllll}
\hline & Gender & $\mathrm{N}$ & Mean & Std. Deviation & Std. Error Mean \\
\hline CTT Inference & Male & 243 & 6.02 & 2.860 & .183 \\
& Female & 307 & 8.48 & 1.999 & .114 \\
\hline
\end{tabular}

Table 16. Results of independent samples T-Test

\begin{tabular}{|c|c|c|c|c|c|c|c|c|}
\hline & & \multicolumn{2}{|c|}{$\begin{array}{l}\text { Levene's Test for } \\
\text { Equality of Variances }\end{array}$} & \multicolumn{5}{|c|}{ t-test for Equality of Means } \\
\hline & & $\mathrm{F}$ & Sig. & $\mathrm{t}$ & $\mathrm{df}$ & $\begin{array}{l}\text { Sig. } \\
\text { (2-tailed) }\end{array}$ & $\begin{array}{l}\text { Mean } \\
\text { Difference }\end{array}$ & $\begin{array}{l}\text { Std. Error } \\
\text { Difference }\end{array}$ \\
\hline \multirow[t]{2}{*}{ CTT Inference } & Equal variances assumed & 66.018 & .000 & -11.808 & 548 & .000 & -2.451 & .208 \\
\hline & Equal variances not assumed & & & -11.344 & 416.081 & .000 & -2.451 & .216 \\
\hline
\end{tabular}

The present study has also found significant difference in the CTT score obtained by male and female students. It shows that female students' performance in critical thinking test $(\mathrm{CTT})$ is better $(\mathrm{M}=8.48, \mathrm{SD}=1.999)$ than male students $(\mathrm{M}=6.02, \mathrm{SD}=2.860)$. The better performance shown on the part of the female students reveals that these students have better critical thinking ability than male students. The results of the independent samples t-test show that the difference in the performance of the participants in CTT based on their gender is significant 
$(\mathrm{p}=.000<0.01)$. This study has also found that the more positive attitude towards critical thinking the students have, the better performance they show in critical thinking test.

Table 17. Location based variance in CTT

\begin{tabular}{llllll}
\hline & Location & $\mathrm{N}$ & Mean & Std. Deviation & Std. Error Mean \\
\hline CTT Inference & Urban & 269 & 7.53 & 2.504 & .153 \\
& Rural & 281 & 7.26 & 2.882 & .172 \\
\hline
\end{tabular}

Table 18. Results of independent samples T-Test

\begin{tabular}{|c|c|c|c|c|c|c|c|c|}
\hline & & \multicolumn{2}{|c|}{$\begin{array}{l}\text { Levene's Test for } \\
\text { Equality of Variances }\end{array}$} & \multicolumn{5}{|c|}{ t-test for Equality of Means } \\
\hline & & $\mathrm{F}$ & Sig. & $\mathrm{t}$ & $\mathrm{df}$ & $\begin{array}{l}\text { Sig. } \\
\text { (2-tailed) }\end{array}$ & $\begin{array}{l}\text { Mean } \\
\text { Difference }\end{array}$ & $\begin{array}{l}\text { Std. Error } \\
\text { Difference }\end{array}$ \\
\hline CTT Inference & $\begin{array}{l}\text { Equal variances assumed } \\
\text { Equal variances not assumed }\end{array}$ & 12.097 & .001 & $\begin{array}{l}1.178 \\
1.182\end{array}$ & $\begin{array}{l}548 \\
542.971\end{array}$ & $\begin{array}{l}.239 \\
.238\end{array}$ & $\begin{array}{l}.272 \\
.272\end{array}$ & $\begin{array}{l}.231 \\
.230\end{array}$ \\
\hline
\end{tabular}

This study has also found that urban students have performed slightly better $(\mathrm{M}=7.53, \mathrm{SD}=2.504)$ than rural students $(\mathrm{M}=7.26, \mathrm{SD}=2.882)$ in critical thinking test $(\mathrm{CTT})$. This shows that urban students have better critical thinking ability than rural students. These results show that the difference in the performance of the participants in CTT based on their location is not significant as p-value is greater than 0.05 . These results reveal that the location of the participants of this affects neither their attitude towards critical thinking nor their performance in critical thinking test.

Table 19. Medium of instruction-based variance in CTT

\begin{tabular}{llllll}
\hline & Medium & $\mathrm{N}$ & Mean & Std. Deviation & Std. Error Mean \\
\hline CTT Inference & English & 445 & 7.51 & 2.649 & .126 \\
& Urdu & 105 & 6.91 & 2.896 & .283 \\
\hline
\end{tabular}

Table 20. Results of independent samples T-Test

\begin{tabular}{|c|c|c|c|c|c|c|c|c|}
\hline & & \multicolumn{2}{|c|}{$\begin{array}{l}\text { Levene's Test for } \\
\text { Equality of Variances }\end{array}$} & \multicolumn{5}{|c|}{ t-test for Equality of Means } \\
\hline & & $\mathrm{F}$ & Sig. & $\mathrm{t}$ & $\mathrm{df}$ & $\begin{array}{l}\text { Sig. } \\
\text { (2-tailed) }\end{array}$ & $\begin{array}{l}\text { Mean } \\
\text { Difference }\end{array}$ & $\begin{array}{l}\text { Std. Error } \\
\text { Difference }\end{array}$ \\
\hline CTT Inference & $\begin{array}{l}\text { Equal variances assumed } \\
\text { Equal variances not assumed }\end{array}$ & 5.430 & .020 & $\begin{array}{l}2.021 \\
1.912\end{array}$ & $\begin{array}{l}548 \\
147.762\end{array}$ & $\begin{array}{l}.044 \\
.058\end{array}$ & $\begin{array}{l}.591 \\
.591\end{array}$ & $\begin{array}{l}.293 \\
.309\end{array}$ \\
\hline
\end{tabular}

The findings of this study reveal that there also exists significant difference in CTT scores for English medium students $(\mathrm{M}=7.51, \mathrm{SD}=2.649)$ and Urdu medium students $(\mathrm{M}=6.91, \mathrm{SD}=2.896)$. The results of the independent samples t-test show that the difference in the performance of the participants in CTT based on their medium of instruction is significant $(\mathrm{p}=.044<0.05)$. This shows that English medium students have better critical thinking ability than Urdu medium students.

The findings of this study related to the variance based on the gender, location and medium of instruction in university students' performance in CTI and CTT reveal that female and English medium students have better performance in CTI and CTT than male and Urdu medium students' and the variance in the performance of these students is significant. The findings of this study also show that there is not significant difference in university students' performance in CTI and CTT based on their location.

\section{Conclusion}

This study has evaluated university students' inference making ability. The results of this study reveal that they have very positive attitude towards inferences making skill and their attitude is a very positive predictor for inference making ability of these students. The findings of this study also demonstrate that university students remain unable to exhibit such performance in inference making test as can match their attitude towards inference making skill of critical thinking. Only $67 \%$ students have been able to score very good in critical thinking test for 
inference making whereas $99.3 \%$ students' have reached this benchmark in exhibiting their attitude towards critical thinking inference.

This study has some pedagogical implication for teaching English as a foreign language in Pakistan. For instance, this study implicates that policy makers and syllabus designers should update syllabus and introduce such activities in textbooks as can be helpful for EFL learners to develop their skill of drawing inferences along with other critical thinking skills. This study would also render an insight into the importance of enhancing and honing the skill of drawing inferences for the EFL learners while reading a piece of text.

\section{References}

Ahour, T., \& Ranjbar, R. (2016). Iranian EFL learners' Lexical Inferencing Strategies at Both Text and Sentence Levels. Iranian Journal of Applied Language Studies, 8(2).

Bos, L. T., Koning, B. B. D., Wasssenburg, I. S., \& Schoot, M. V. D. (2016). Training Inference Making Skills Using a Situation Model Approach Improves Reading Comprehension. Frontiers in Psychology, 7, February. https://doi.org/10.3389/fpsyg.2016.00116

Cain, K., \& Oakhill, J. (1999). Inference Making Ability and Its Relation to Comprehension Failure in Young Children. Reading and Writing: An Interdisciplinary Journal, 11, 489-503. https://doi.org/10.1023/A:1008084120205

Cain, K., Oakhill, J. V., Barnes, M. A., \& Bryant, P. E. (2001). Comprehension Skill, Inference-Making Ability, and their Relation to Knowledge. Memory \& Cognition, 29(6), 850-859. https://doi.org/10.3758/BF03196414

Currie, N. K., \& Cain, K. (2015). Children's Inference Generation: The Role of Vocabulary and Working Memory. Journal of Experimental Child Psychology, 137, 57-75. https://doi.org/10.1016/j.jecp.2015.03.005

Dornyei, Z. (2011). Research Methods in Applied Linguistics. Oxford University Press.

Facione, P. A., \& Facione, N. C. (1992). The California Critical Thinking Disposition Inventory. Millbrae, CA: California Academia Press.

Fahimeh, B., \& Afsneh, G. (2016). The Effect of Inference-Making, Deduction, and Self-Monitoring on EFL Learners' Language Achievement, Reading, and Writing Ability. International Journal of Research Studies in Language Learning, 5(4). https://doi.org/10.5861/ijrsll.2015.1320

Graesser, A. C., Singer, M., \& Trabasso, T. (1994). Constructing Inferences During Narrative Text Comprehension. Psychological Review, 101(3), 371-395. https://doi.org/10.1037/0033-295X.101.3.371

Halpern, D. (2003). Thought \& Knowledge: An Introduction to Critical Thinking; Lawrence Erlbaum Associates. Publishers London; 2003 Mahwah, New Jersey.

Hashemi, M. R., \& Zahibi, R. (2012). Does Critical Thinking Enhance EFL Learners' Receptive Skills. Journal of Language Teaching and Research, 3(1), 172-179. https://doi.org/10.4304/jltr.3.1.172-179

Hassanzadeh, Z., Tamjid, N. S., \& Ahangari, S. (2019). The Effect of Inference Strategy Instruction on Iranian EFL Learners' Vocabulary Depth and Breadth. Cogent Education, 6, 1614750. https://doi.org/10.1080/2331186X.2019.1614750

Kispal, A. (2008). Effective teaching of inference skills for reading. Literature review. National Foundation for Educational Research. Department for Children, Schools and Families. Great Britain. Research Report No. DCSF-RR031.

Marzano, R. J. (2010). Teaching Inference (pp. 80-82). The Art and Science of Teaching, Educational Leadership/April 2010.

McArthur, T. (1992). The Oxford Companion to the English Language (p. 515). Oxford New York, Oxford University Press.

Oakhill, J. V., \& Cain, K. (1999). Inference Making Ability and its Relation to Comprehension Failure in Young Children. Reading and Writing: An Interdisciplinary Journal, 11, 489-503. https://doi.org/10.1023/A:1008084120205

Paul, R., \& Elder, L. (2011). Critical Thinking: Tools for Taking Charge of Your Learning and Your Life (3rd ed.). Pearson.

Savic, M. V. (2018). Reading in English: Inference Skills of Young Language Learners. HB год, 67(2), 285-296. 
https://doi.org/10.5937/nasvas1802285S

Schoot, M. V. D. et al. (2016). Training Inference Making Skills Using a Situation Model Approach Improves Reading Comprehension. Front. Psychol., 7, 1-13. https://doi.org/10.3389/fpsyg.2016.00116

van den Broek, P., Beker, K., \& Oudega, M. (2015). Inference generation in text comprehension: Automatic and strategic processes in the construction of mental representation. In E. J. O’Brien, A. E. Cook \& R. F. Lorch (Eds.), Inferences during reading (pp. 94-121). Cambridge, UK: Cambridge University Press. https://doi.org/10.1017/CBO9781107279186.006

Wardinah, N., Suwarno, B., \& Arono. (2016). Students' Difficulties in Making Inference in Reading Narrative Passages at the Social Eleventh Grade of SMAN 1 CURUP. Journal of Applied Linguistics and Literature, 2(2), 78-94.

Watson, G. B., \& Glaser, E. M. (2002). Watson-Glaser Critical Thinking Appraisal UK. London: The Psychological Corporation.

\section{Copyrights}

Copyright for this article is retained by the author, with first publication rights granted to the journal.

This is an open-access article distributed under the terms and conditions of the Creative Commons Attribution license (http://creativecommons.org/licenses/by/4.0/). 